\title{
Annual
}

\section{Site Environmental Report}

\section{Calendar Year 2005}

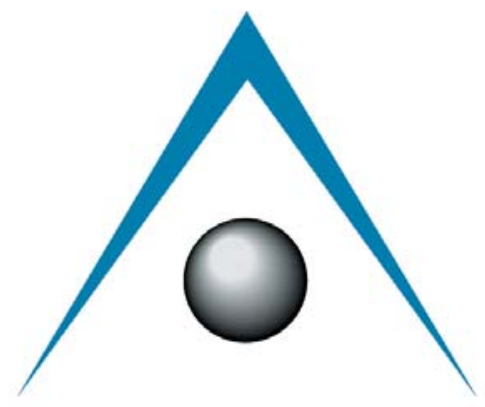

\section{AMES LABORATORY}

Iowa State University

Ames, lowa 50011-3400

Prepared for the

U.S. Department of Energy

Under Contract No. W-7405-ENG-82 
Feedback Form

2.0 INTRODUCTION

2.1 Site Description

2.2 Organization and Administration 5

Figure 2.2-1 Organizational Chart 6

2.3 Mission $\quad 7$

2.4 Purpose of Site Environmental Report $\quad 7$

3.0 COMPLIANCE SUMMARY

3.1 Calendar Year 2005 Compliance Status 7

3.2 Comprehensive Environmental Response, Compensation 7

and Liability Act (CERCLA)

3.3 Resource Conservation and Recovery Act (RCRA) 8

3.4 Federal Facilities Compliance Act (FFCA) 8

3.5 National Environmental Policy Act (NEPA) 9

3.6 Clean Air Act (CAA) and National Emissions Standards for 9

Hazardous Air Pollutants (NESHAPS)

3.7 Clean Water Act (CWA) 9

3.8 Safe Drinking Water Act (SDWA) 10

Table 3.8-1 Drinking Fountain Analysis 10

3.9 Superfund Amendments and Reauthorization Act (SARA)Title III 10 and lowa Administrative Code (IAC), Rule 567, Chapter 131, Spill Response

Table 3.9-1 Status of EPCRA Reporting

3.10 Toxic Substances Control Act (TSCA)

3.11 Federal Insecticides, Fungicide and Rodenticide Act (FIFRA) 11

3.12 Endangered Species Act (ESA) 11

3.13 National Historic Preservation Act (NHPA) 11

3.14 Migratory Bird Treaty Act $\quad 12$

3.15 Executive Order 11988, "Floodplain Management" 12

3.16 Executive Order 11990, "Protection of Wetlands" 12

3.17 Summary of Permits $\quad 12$

Table 3.17-1 DOE Air Emissions Source Construction Permit Numbers 12

Table 3.1.7-2 DOE RCRA Generator Identification Numbers 12

\section{$\begin{array}{ll}\text { 4.0 ENVIRONMENTAL PROGRAM } & 13\end{array}$}

4.1 Environmental Management System 13

4.1.1 EMS Effectiveness 13

4.2 Pollution Awareness, Waste Minimization and Recycling Programs 13

$\begin{array}{ll}\text { 4.3 Performance Measures } & 14\end{array}$ 
5.0 ENVIRONMENTAL RADIOLOGICAL PROGRAM 15

5.1 DOE Order 5400.5, "Radiation Protection of the Public 15 and the Environment"

5.2 DOE Order 435.1, "Radioactive Waste Management" 15

5.3 Property Release $\quad 15$

5.4 Radiation Emissions and Doses $\quad 15$

5.5 Unplanned Releases $\quad 15$

5.6 Environmental Monitoring 16

5.7 Areas of Concern 16

5.7.1 Chemical Disposal Site (CDS) 16

Table 5.7-1 CDS Groundwater Analysis 17

5.7.2 Inactive Waste Sites (IWS) 18

5.7.3 Former lowa State College Dump Site 18

5.7.4 Fire Service Institute Training Area 18

5.7.5 Waste Handling Facility (WHF) 19

6.0 ENVIRONMENTAL NON-RADIOLOGICAL PROGRAM 20

6.1 National Pollutant Discharge Elimination System (NPDES) Data 20

6.2 Other Emissions Monitoring 20

6.3 Continuous Release Reporting 20

6.4 Environmental Occurrences 20

6.5 SARA Title III Reporting Requirements 20

$\begin{array}{ll}\text { 7.0 GROUNDWATER MONITORING AND PROTECTION } & 21\end{array}$

$\begin{array}{ll}\text { 8.0 QUALITY ASSURANCE PROGRAMS } & 21\end{array}$

$\begin{array}{ll}9.0 & 23\end{array}$

$\begin{array}{ll}10.0 \text { LIST OF ACRONYMS } & 25\end{array}$

$\begin{array}{ll}\text { 11.0 REPORT DISTRIBUTION } & 28\end{array}$

APPENDIX A (Chemical Disposal Site (CDS) Correspondences) 33

1) Letter to IDPH requesting release of the CDS, September 30, 1998.

2) Letter from IDPH granting "unrestricted" release of the CDS, October 15, 1998.

3) Letter from IDPH to Edward J. Stanek, II, Ph.D., status of CDS, October 16, 1998.

4) Letter from ISU to DOE-Ames Group, October 22, 1998. 
APPENDIX B (Air Permit Correspondences)

1) Letter from IDNR exempting laboratory fume hoods from permitting, July 18, 1994.

2) Letter from Jacobs Engineering Group Inc. exempting graphics paint spray booth from permitting, July 16, 1997.

3) Letter from IDNR exempting graphite lathe hood exhaust from permitting, February 6, 1998.

4) U.S. Department of Energy Air Emissions Annual Report, Calendar Year 2005.

APPENDIX C (Inactive Waste Site Correspondences)

1) Letter from IDPH, Closure of nine waste sites, January 11, 1996.

2) Letter from DOE-CH, Regarding the lowa State College Dump Site, April 20, 1999.

3) Letter from IDPH, Closure of the Former lowa State College Dump Site, September 17, 2001.

4) Letter from IDPH, Closure of the Fire Service Institute Training Area, February 26, 2002.

APPENDIX D (EPA \& DOE Correspondences)

1) EPA letter (NOV's), April 6, 1999.

2) EPA e-mail status of CDS and WHF EPA ID Numbers, July 8, 2003.

3) DOE-CH letter approving Laboratory's EMS, December 21, 2005. 


\subsection{EXECUTIVE SUMMARY}

This report summarizes the environmental status of Ames Laboratory for calendar year 2005. It includes descriptions of the Laboratory site, its mission, the status of its compliance with applicable environmental regulations, its planning and activities to maintain compliance, and a comprehensive review of its environmental protection, surveillance and monitoring activities.

Ames Laboratory is located on the campus of lowa State University (ISU) and occupies 11 buildings owned by the Department of Energy (DOE). See the Laboratory's Web page at www.external.ameslab.gov for locations and Laboratory overview. The Laboratory also leases space in ISU owned buildings.

In 2005, the Laboratory accumulated and disposed of waste under U.S. Environmental Protection Agency (EPA) issued generator numbers. All waste is handled accordingly to all applicable EPA, State, Local and DOE Orders.

The most recent RCRA inspection was conducted by EPA Region VII in January 1999. The Laboratory received a notice of violation (NOV) which included five citations. There have been no inspections since then. The citations were minor and were corrected by the Laboratory within the time allocated by the EPA. See correspondence in Appendix D.

The Laboratory was in compliance with all applicable federal, state, local and DOE regulations and orders in 2005.

There were no radiological air emissions or exposures to the general public due to Laboratory activities in 2005. See U.S. Department of Energy Air Emissions Annual Report in Appendix B.

Pollution awareness, waste minimization and recycling programs were implemented in 1990 and updated in 2003. Included in these efforts were battery and CRT recycling, waste white paper and green computer paper-recycling. Ames Laboratory also recycles/reuses salvageable metal, used oil, styrofoam peanuts, batteries, CRTs, fluorescent lamps and telephone books. .

Ames Laboratory reported to DOE-CH, through the Laboratory's Self Assessment Report, on its Affirmative Procurement Performance Measure. A performance level of "outstanding" was achieved in 2005.

The Laboratory underwent a voluntary Environmental Management Review (EMR) in 2003. Members of the Environmental Protection Agency (EPA) Region VII and lowa Department of Natural Resources (IDNR) conducted the EMR in November 2003. The EMR was conducted as part of the process for developing and implementing an Environmental Management System (EMS) at the Laboratory. The final EMR report was received on June 19, 2003. Most of the recommendations were implemented to fulfill the EMS requirements for the ISO 14001:1996 standard. In 2004, the Laboratory "Self Declared" that it had fully integrated an EMS with its Integrated Safety Management System (ISMS) and met the requirements of Executive Order 13148. In November of 2005 DOE-CH conducted a self-declaration assessment of the 
Laboratory's EMS. The assessment found two nonconformities that the Laboratory promptly corrected, allowing the DOE-CH Ames Site Office to accept the Laboratory's self-declaration (See EMS Assessment letter, December 21, 2005 in Appendix D). 


\section{Ames Laboratory Site Environmental Report Feedback Form}

This feedback form is provided to solicit public input on the development and improvement of future SER's. Public input is encouraged and appreciated. Remove and copy as needed. Attach additional pages as needed or send comments to kayser@ameslab.gov.

Return to: Ames Laboratory

Environment, Safety, Health \& Assurance

G40 TASF, lowa State University

Ames, IA 50011-3400

ATTN: Dan Kayser

1. What prompted your interest in environmental activities at Ames Laboratory?

2. In what ways can this report document and/or format be improved?

3. Do you have any questions on specific items or issues in this report?

4. Do you have any other comments? 


\subsection{INTRODUCTION}

\subsection{Site Description}

Ames Laboratory is a U.S. DOE facility located on the campus of lowa State University (ISU) at Ames, lowa. See the Laboratory's Web page at www.external.ameslab.gov for locations and Laboratory overview. Ames is a government-owned, contractor-operated (GOCO) facility. ISU is the Laboratory's contractor. The Technical and Administrative Services Facility (TASF) houses most of the Laboratory's management offices. The buildings owned by the Department of Energy (DOE) are listed below.

\section{Building}

Spedding Hall

Metals Development Building

Wilhelm Hall

TASF

Campus Warehouse Building

Mechanical Maintenance Building

Paint and Air Conditioning Shops

Construction Storage Shed

Storage Shed

Records Storage

Storage Shed

Total DOE Owned

\section{Gross Square Feet}

107,630

69,663

56,541

46,991

16,506

8,540

4,954

4,398

2,100

1,679

500

327,102

In addition to the buildings owned by the DOE, Ames Laboratory leased a net total of 27,889 square feet of space from ISU in 2005. In 1987 the DOE transferred ownership of the buildings it owned at the Applied Science Complex (ASC) site to ISU. Ames Laboratory will retain beneficial use of the Waste Handling Facility (WHF) and the High Pressure Test Cell at the ASC through February 28, 2060. The WHF housed the Alpha Facility, a laboratory that was designed to use small amounts of radionuclides. The Alpha Facility was gutted and surveyed for radioactive contamination. The WHF has no further use and has become a maintenance burden over the years. The WHF and the Alpha Facility are slated to be demolished in 2006 (see section 5.7.5) pending the availability of funding. The ASC is located one-mile northwest of ISU's main campus. See Web pages at www.external.ameslab.gov/common/amesmap.html. Click on lowa State University Campus Map.

The City of Ames, lowa surrounds the ISU main campus. In 2005 the population of Ames was approximate 53,284 , which includes the ISU student population of approximately 25,400 . Ames is located in Story County, which has a population of 80,204 . 
The climate is temperate continental, and is subject to wide temperature and precipitation ranges throughout the year. Mean monthly temperature varies from a low of minus 7.5 degrees Celsius $\left(18.5^{\circ} \mathrm{F}\right)$ in January to a high of 23.8 degrees Celsius $\left(74.8^{\circ} \mathrm{F}\right)$ in July. Average rainfall equivalent precipitation varies from 1.8 centimeters (0.7 inches) in January to 13.7 centimeters (5.4 inches) in June.

The region's topography is gently rolling with a slight overall gradient to the southeast. Under the shallow topsoil, the soils are glacial till with a depth of approximately 19.8 meters (65 feet). This material is underlain by predominantly limestone bedrock. In the central campus area, the depth to first groundwater is approximately 3.0 meters ( 10 feet). At the ASC site depth to groundwater averages approximately 5.5 meters (18 feet). Surface run-off from both areas flows into Squaw Creek, a tributary of the South Skunk River. The streams have a combined average daily flow of approximately 644 million liters (170 million gallons).

\subsection{Organization and Administration}

lowa State University operates Ames Laboratory for the United States government under Contract Number W-7405-ENG-82 with the U.S. DOE. The DOE Office of Science, through the Ames Site Office, administers the contract. Ames Laboratory is a member of the Institute for Physical Research and Technology (IPRT), a network of scientific research centers at ISU. In 2005, the Laboratory employed a total of 676 people. 442 full and part time employees and 234 associate (non-payroll) employees. See Organizational Chart Figure 2.2-1. 


\section{Ames Laboratory \\ Organization}

s

AMES LABORATORY

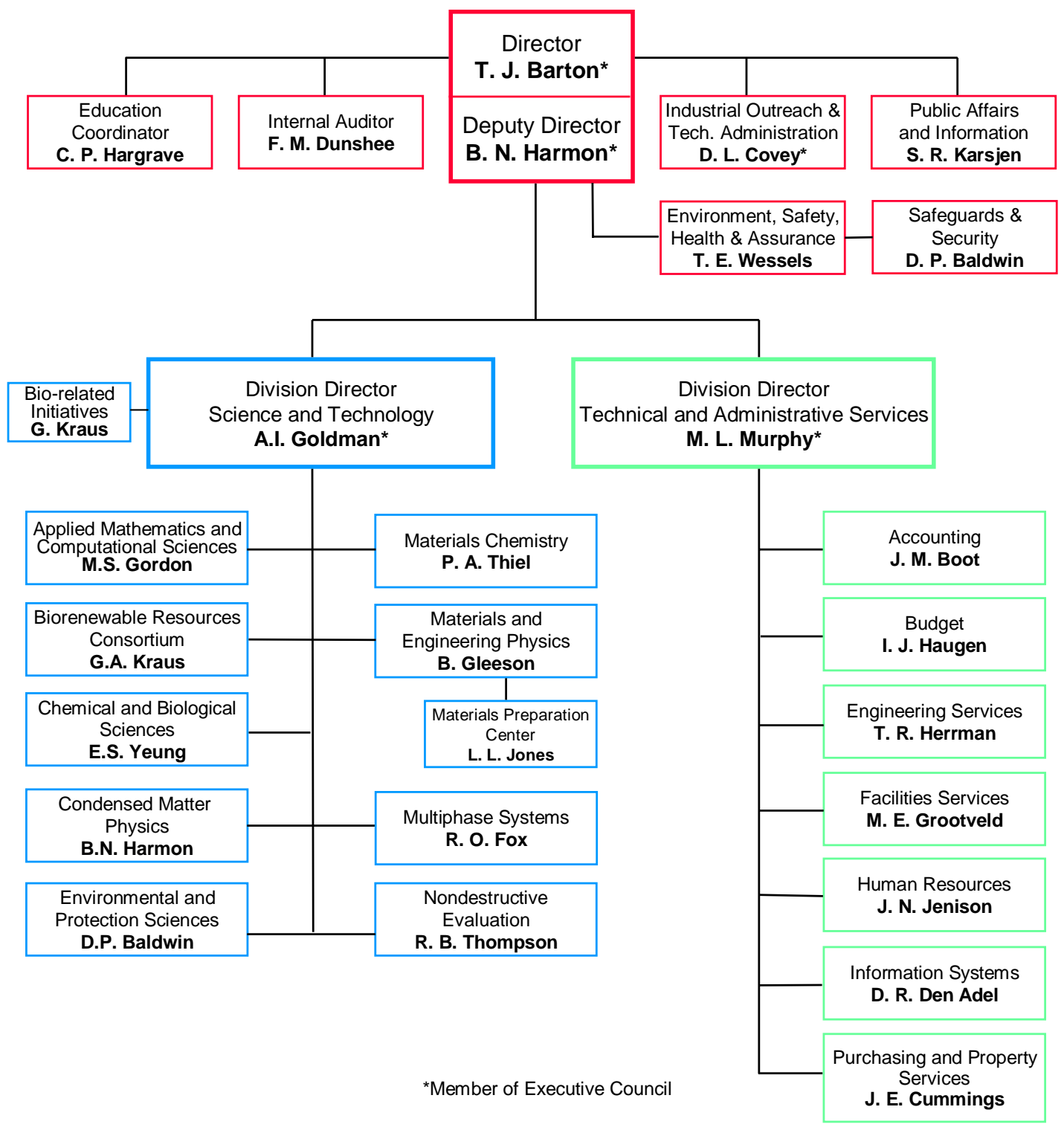

October 2005

Figure 2.2-1 


\subsection{Mission}

The Laboratory's mission is to conduct fundamental research in the physical, chemical, materials, and mathematical sciences and physics, which underlie energy generating, conversion, transmission and storage technologies, environmental improvement, and other technical areas essential to national needs. These efforts will be maintained so as to contribute to the achievement of the Department of Energy's missions and goals; more specifically, to increase the general level of scientific knowledge and capability, to prepare engineering and physical sciences students for future scientific endeavors, and to initiate nascent technologies and practical applications arising from the Laboratory's scientific programs.

The Laboratory will approach all of its operations with the safety and health of all workers as a constant objective and with genuine concern for the environment. Ames Laboratory does not conduct classified research.

\subsection{Purpose of Site Environmental Report}

The primary purpose of this report is to summarize the performance of Ames Laboratory's environmental programs, present highlights of significant environmental activities, and confirm compliance with environmental regulations and requirements for calendar year 2005. This report is a working requirement of Department of Energy Order 231.1, Environment, Safety, and Health Reporting".

\subsection{COMPLIANCE SUMMARY}

\subsection{Calendar Year 2005 Compliance Status}

The Laboratory was in compliance with all applicable environmental regulations in 2005.

\subsection{Comprehensive Environmental Response, Compensation and Liability Act (CERCLA)}

There were no sites regulated under CERCLA.

Proper public comment periods have been observed for former site restoration activities (See section 5.7). The community advisory group (CAG), formed in May 1994, was and is the primary vehicle for public input to these activities. The CAG met with Ames Laboratory and ISU representatives on February 23, 1998, to discuss corrective actions proposed for the Fire Service Institute Training Area (FSITA). The most recent interaction with CAG members include a letter regarding the Energy Employees Occupational Illness Compensation Program Act (EEOICP) and a letter regarding the Laboratory's support of the Special Exposure Cohort Petition for employees who worked at the Laboratory from 1942-1955. EEOICP's mission is to deliver benefits to eligible employees and former employees of the Department of Energy, its contractors and subcontractors or to certain survivors of such individuals, as provided in the EEOICP Act. 


\subsection{Resource Conservation and Recovery Act (RCRA)}

Ames Laboratory is a government-owned, contractor-operated (GOCO) facility. All waste generated by Ames Laboratory under the contract with DOE is DOE waste. In 2005, DOE had one active RCRA site and two inactive sites. (See the summary table in section 3.17). Activities associated with the main campus EPA ID number were those of a large quantity generator. In calendar year $2005,1,412 \mathrm{~kg}$ of hazardous waste was properly disposed of through a contracted vendor. All reporting requirements were met. The Waste Handling Facility (WHF) and the Chemical Disposal Site (CDS) have been designated by EPA as "non-generator" sites (See correspondence in APPENDIX D). The WHF location does not store RCRA hazardous waste or mixed waste and is slated for demolition in 2006 (See section 5.7.5). The CDS waste removal was completed in 1995 (See section 5.7.1 and correspondences in APPENDIX A).

The Laboratory's biennial report (aka: Hazardous Waste Report) to the EPA for calendar year 2003 was completed and submitted on time in February 2003. The report is required of all large quantity generators and is a record of wastes removed from the facility. The next report is due March 1, 2006.

The Laboratory disposed of wastes at an out of state EPA permitted facility. It is the Laboratory's practice to have RCRA regulated wastes and other waste like materials incinerated, whenever possible. Incineration ensures the complete destruction of most hazardous constituents and reduces waste volumes. Incinerator emissions are highly regulated as well as the ash and slag produced. The slag and ash is disposed of in a permitted landfill.

There were four shipments of RCRA waste and one shipment of low-level radioactive waste in 2005. No mixed waste was generated or disposed of in 2005.

The Laboratory had no underground storage tanks (UST's) in 2005. The last UST (emergency generator diesel fuel) was removed in August 1995. It was replaced with an aboveground, double walled diesel tank with interstitial leak detection. There were no problems associated with the tank in 2005.

\subsection{Federal Facilities Compliance Act (FFCA)}

The FFCA is part of 42 USC 6901 and amends a part of RCRA. FFCA requires the preparation of site treatment plans for the handling of mixed wastes. EPA approved the Ames Laboratory Site Treatment Plan (STP) in January 1996.

Two waste streams were not included in the final STP because the Laboratory found process treatments that avoided creating mixed waste and, therefore, avoided the effort and expense of managing mixed wastes: 1) transuranic waste has been managed according to applicable state and federal regulations as well as applicable DOE orders. Transuranic solutions were neutralized and stabilized in the fall of 2000. The stabilized material $\left(0.25 \mathrm{~m}^{3}\right)$ was sent to Hanford as LLW in 2001; 2) contaminated lead was eliminated from the STP because in-process treatment prevents it from meeting the definition of mixed waste. 
Any newly generated mixed waste will be handled and disposed of accordingly to EPA, state, local and DOE orders.

\subsection{National Environmental Policy Act (NEPA)}

The Laboratory had one categorical exclusion (CX) determination in 2005 that involved facility upgrades. All other activities were covered under the Laboratory's "site-wide" categorical exclusion for "Indoor Bench-Scale Research Projects and Conventional Laboratory Operations" which was submitted and approved by DOE-CH This exclusion is valid through September 2008. This "site-wide" CX eliminates unnecessary documentation but will still uphold the integrity of NEPA. Categorical exclusions are classes of actions that DOE has determined do not individually or cumulatively have a significant effect on the environment and do not require the preparation of either an environmental assessment or an environmental impact statement.

\subsection{Clean Air Act (CAA) and National Emissions Standards for Hazardous Air Pollutants (NESHAPS)}

U.S. EPA Region VII has delegated CAA authority to the State of lowa Department of Natural Resources (IDNR). The IDNR issued an official ruling for Ames Laboratory on July 18, 1994, stating that no permitting and no monitoring is required for the Laboratory's fume hoods.

The Laboratory maintains two construction air permits which were issued by the IDNR in December 1996. These are for the paint booth and sand blaster. A paint booth in the Ames Laboratory Graphics department is exempt from permitting. (See correspondence in APPENDIX B and section 3.17 for a summary of permits).

The Laboratory was in compliance with all CAA requirements, including the NESHAP regulations for radionuclide emissions from DOE facilities. The Laboratory used small quantities of chemicals and radioactive materials for laboratory bench-top research and development activities in 2005. Any air emissions generated by Ames Laboratory research activities were de minimis. The Laboratory did not have any air emissions in 2005 that could have exposed the public to radioactivity (See correspondences in APPENDIX B).

\subsection{Clean Water Act (CWA)}

Ames Laboratory does not have any point sources of effluents requiring National Pollutant Discharge Elimination System (NPDES) permits. The Laboratory discharges all liquid wastes to the ISU sanitary sewer system, which discharges into the City of Ames sanitary sewer system. The City of Ames has an NPDES permit. The City of Ames has an agreement for wastewater pre-treatment with ISU, which includes Ames Laboratory's wastewater. Both the City of Ames and ISU sampled the university's wastewater effluent in 2005 as part of this agreement. The Laboratory discharged approximately $25,241,587$ liters $(6,731,090$ gallons) of wastewater to ISU's sanitary sewer system in 2005 . This was 3.50 percent of the total discharged from ISU's campus buildings. The university discharged 707,016,413 liters (188,537,710 gallons) of wastewater to the City of Ames sewer system. 


\subsection{Safe Drinking Water Act (SDWA)}

Drinking water for the Laboratory is supplied by the City of Ames public water system through the university's water mains. The Ames public water system is tested by the city to verify SDWA standards are being met. The Laboratory used $25,241,587$ liters $(6,731,090$ gallons) of potable water in 2005 , or less than 1.0 percent of the $1,079,183,685$ liters $(287,782,316$ gallons $)$ used by the university.

Ames Laboratory Facilities Services sampled three drinking fountains for lead in 2005. Fountains in Wilhelm Hall, Metals Development and Spedding Hall were monitored in accordance with the Laboratory's Monitoring Lead in Potable Water (46300.002) policy. An independent laboratory did the analysis. All samples were within regulatory limits for lead. The results are summarized in Table 3.8-1.

Table 3.8-1

\section{Drinking Fountain Analysis}

\begin{tabular}{|c|c|c|c|c|c|c|}
\hline $\begin{array}{l}\text { Building } \\
\text { Location }\end{array}$ & $\begin{array}{l}1999 \text { Lead } \\
\text { (mg/l) }\end{array}$ & $\begin{array}{l}2000 \text { Lead } \\
\text { (mq/l) }\end{array}$ & $\begin{array}{l}2001 \text { Lead } \\
\text { (mg/L) }\end{array}$ & $\begin{array}{c}2002 \\
(\mathrm{mg} / \mathrm{L})\end{array}$ & $\begin{array}{c}2003 \\
(\mathrm{mg} / \mathrm{L})\end{array}$ & $\begin{array}{l}2005 \\
(\mathrm{mg} / \mathrm{L})\end{array}$ \\
\hline $\begin{array}{l}\text { Spedding Hall, } \\
1^{\text {st }} \text { floor west } \\
\text { hallway }\end{array}$ & & $<0.002$ & & & & \\
\hline $\begin{array}{l}\text { Spedding Hall, } \\
\text { ground floor east } \\
\text { hallway }\end{array}$ & $<0.002$ & & $<0.002$ & $<0.005$ & $<0.005$ & $<0.005$ \\
\hline $\begin{array}{l}\text { Wilhelm Hall, } 3^{\text {rd }} \\
\text { floor east hallway }\end{array}$ & $<0.002$ & $<0.002$ & $<0.002$ & $<0.005$ & $<0.005$ & $<0.005$ \\
\hline $\begin{array}{l}\text { Metals } \\
\text { Development, } \\
\text { room } 158\end{array}$ & $<0.002$ & $<0.004$ & $<0.002$ & $<0.005$ & $<0.005$ & $<0.005$ \\
\hline
\end{tabular}

* The regulatory limit for lead is $0.015 \mathrm{mg} / \mathrm{l}$.

3.9 Superfund Amendments and Reauthorization Act (SARA) Title III and lowa Administrative Code (IAC), Rule 567, Chapter 131, Spill Response

The Laboratory was not required to report under the Emergency Planning \& Community Right to Know Act (EPCRA) Sections 302-303, 311-312,313 in 2005. The Laboratory did not store any chemicals in excess or near EPCRA threshold limits in 2005. The Laboratory does maintain memorandums of understanding (MOU) with the lowa State University Department of Pubic Safety and the City of Ames Fire Department for emergency and hazardous material situations. Copies of MOU's are located in the "Ames Laboratory Emergency Plan". The Laboratory was not required to report under EPCRA Section 304 as there were no reportable releases.

Spills to the environment are reported to the lowa Department of Natural Resources in accordance with the IAC, Rule 567, Chapter 131. Spills are cleaned up in accordance 
with the IAC, Rule 567, Chapter 133 . There is no minimum reportable quantity under Chapter 131. There were no reportable environmental spills in 2005.

Reportable spills, releases and occurrences are entered in DOE's Occurrence Reporting and Processing System (ORPS) as prescribed in DOE Order 232.1A. The Laboratory also reports any "reportable" spills/releases to DOE-CH on a quarterly basis.

Table 3.9-1

Status of EPCRA Reporting

\begin{tabular}{|l|l|c|}
\hline \multicolumn{1}{|c|}{ EPCRA Section } & \multicolumn{1}{c|}{ Description of Reporting } & \multicolumn{1}{c|}{ Status } \\
\hline EPCRA Sec. $302-303$ & Planning Notification & Not Required \\
\hline EPCRA Sec. 304 & EHS Release Notification & Not Required \\
\hline EPCRA Sec. 311-312 & MSDS/Chemical Inventory & $\begin{array}{c}\text { Voluntarily Reporting/Not } \\
\text { Required }\end{array}$ \\
\hline EPCRA Sec. 313 & TRI Reporting & Not Required \\
\hline
\end{tabular}

\subsection{Toxic Substances Control Act (TSCA)}

No asbestos containing material (ACM) was disposed of in 2005. Ames Laboratory ACM is disposed of in the Ames-Story Environmental Landfill. The landfill is permitted to accept ACM under IDNR issued permit number 85-SDP-13-91P. The Laboratory complies with the State of lowa Solid Waste Disposal Rule \#102.14 and 40 CFR 61, Subpart M (asbestos NESHAP) when disposing of ACM.

Approximately $157 \mathrm{~kg}$ of PCB ballasts were disposed in 2005 .

\subsection{Federal Insecticide, Fungicide, and Rodenticide Act (FIFRA)}

Ames Laboratory does not purchase or use pesticides regulated by FIFRA. Pesticide spraying is done in portions of buildings by a licensed applicator using approved chemicals.

\subsection{Endangered Species Act (ESA)}

No endangered species have been identified on or near Ames Laboratory facilities or Laboratory controlled areas.

\subsection{National Historic Preservation Act (NHPA)}

The State Historic Preservation Officer was contacted in 1997. As of September 16, 1997, there are nine structures on the campus, of lowa State University, that are on the state historic register. None of these buildings is associated with Ames Laboratory activities. DOE does not own any of the land upon which Ames Laboratory's buildings stand. Ames Laboratory has not conducted a formal archeological survey. The Laboratory has no plans to remove or significantly modify its facilities or remove 
historical equipment. The evaluation of cultural/historical resources was incorporated into procedure 10200.054. Funding for a formal archeological survey has not been prioritized above existing facility maintenance, safety or security needs.

\subsection{Migratory Bird Treaty Act}

There are over 200 bird species that may migrate through Ames, IA. However, there are no activities at the Ames Laboratory that affect migratory birds.

\subsection{Executive Order 11988, "Floodplain Management"}

All Laboratory facilities are well outside the 100-year flood line as mapped by the U.S. Geological Survey (USGS) and the lowa Geological Survey Bureau (GSB). The Lab is in full compliance with 10CFR 1022.

\subsection{Executive Order 11990, "Protection of Wetlands"}

No wetlands are affected by Ames Laboratory activities. The Lab is in full compliance with 10CFR 1022.

\subsection{Summary of Permits}

In 2005, Ames Laboratory had two air emissions source construction permits, but it had no environmental discharge, operational, storage, treatment or disposal permits for gaseous, liquid or solid effluents. DOE held three waste generator identification numbers for Ames Laboratory in 2005, although two of the sites were inactive.

Table 3.17-1

\section{DOE Air Emissions Source Construction Permit Numbers}

\begin{tabular}{|l|c|l|l|}
\hline \multicolumn{1}{|c|}{ Permit Number } & Type & Ames Laboratory FacilitylArea & \multicolumn{1}{|c|}{ Expiration } \\
\hline $96-A-1282$ & Air & Ames Lab Paint Booth & None \\
\hline $96-A-1283$ & Air & Ames Lab Sand Blaster & None \\
\hline
\end{tabular}

Table 3.17-2

\section{DOE RCRA Generator Identification Numbers}

\begin{tabular}{|l|l|l|l|}
\hline \multicolumn{1}{|c|}{ RCRA Generator ID \# } & \multicolumn{1}{|c|}{ Type } & \multicolumn{1}{|c|}{ Ames Laboratory FacilitylArea } & \multicolumn{1}{|c|}{ Expiration } \\
\hline IA6890008950 & LQG & Ames Lab \#3-DOE (main campus) & None \\
\hline * IAD984617605 & CESQG & $\begin{array}{l}\text { Ames Lab \#1-DOE (Waste Handling } \\
\text { Facility) }\end{array}$ & None \\
\hline * IA0000365973 & SQG & $\begin{array}{l}\text { Ames Lab \#2-DOE/ISU (chemical } \\
\text { disposal site) }\end{array}$ & None \\
\hline
\end{tabular}

* Both sites have been designated by the EPA as "non-generators". 


\subsection{ENVIRONMENTAL PROGRAM}

\subsection{Environmental Management System}

The Laboratory's Environmental Management System (EMS) is incorporated into the Laboratory's Integrated Management System (ISMS). The Laboratory's EMS web link is http://www.external.ameslab.gov/esha/Worksmartstd/EMS.htm which contains relevant policies and procedures to the Laboratory's EMS.

\subsubsection{EMS Effectiveness}

The Laboratory's EMS has been effective. Due to basic research at the Laboratory environmental aspects do not drastically change. However, with the integration into the Laboratory's Integrated Management System (ISMS) there are systems in place to adequately detect new environmental aspects and impacts. The Laboratory has an Environmental Management System Steering Group that consists of researchers, safety personnel, facilities personnel, transportation and procurement personnel. This group is tasked with recommending energy savings goals for the Laboratory. These recommendations are tracked in the Laboratory's database (Ames Laboratory Corrective Action Tracking System - ALCATS). Energy usage was determined to be the significant aspect (largest impact on the environment) for the Laboratory. The Laboratory has taken measures (i.e. facility upgrades, education, reduced lighting at off peak hours) and continues to look at other areas of energy conservation. The Group has also been instrumental in developing new training aids to promote and maintain the Laboratory's EMS.

\subsection{Pollution Awareness, Waste Minimization and Recycling Programs}

Ames Laboratory's waste minimization plan was implemented in 1990. The plan was updated in 2003. The plan conforms to Executive Order 13101. Elements of the plan include:

\footnotetext{
$>$ A statement of management support and commitment.

$>$ A waste minimization policy for the Laboratory.

$>$ Goals.

$>$ Waste minimization and recycling activities.

$>$ Employee awareness.

$>$ Affirmative procurement program.
} 
The Laboratory was engaged in waste minimization activities in 2005. These activities helped reduce the quantities of non-hazardous and hazardous wastes generated by the Laboratory. Examples include:

$>$ Steel recycling.

$>$ White paper and computer paper are recycled.

$>$ Styrofoam peanut recycling.

$>$ Chemical surplus redistribution.

$>$ Telephone book recycling.

$>$ Fluorescent bulb recycling.

$>$ CRT recycling.

$>$ Battery recycling.

All other non-hazardous waste generated by the Laboratory (e.g. cardboard, garbage, trash) was collected and transported to the City of Ames' Resource Recovery Plant for processing. Combustible waste is used as fuel in the city's electrical utility power plant. Scrap metal from uncontrolled areas is sent offsite for recycling. Ames Laboratory's Facility Services Group recovers R-12 refrigerants, except from vehicles, and R-22 refrigerants for recycling. Recovery equipment is registered with EPA Region VII under Number 608. Freon is recycled through the Laboratory's waste disposal vendor.

\subsection{Performance Measures}

For calendar year 2005, Ames Laboratory reported to DOE-CH through the Laboratory's Self Assessment Report on its Affirmative Procurement Performance Measure. The Laboratory strives to purchase EPA-designated items to the maximum extent practicable. The Laboratory's rating of 100 percent translates to a performance level of "Outstanding". 


\subsection{ENVIRONMENTAL RADIOLOGICAL PROGRAM}

\subsection{DOE Order 5400.5, "Radiation Protection of the Public and the Environment"}

Ames Laboratory has prepared guidance documents, which are based on the environmental radiation release criteria specified in DOE Order 5400.5. There were no detectable or reportable radiological releases to the environment in 2005 (See U.S. Department of Energy Air Emissions Annual Report, Calendar Year 2005 in Appendix B).

\subsection{DOE Order 435.1, "Radioactive Waste Management"}

The majority of the Laboratory's radioactive waste is generated through renovation activities that occur in DOE buildings. These buildings were contaminated by past activities. All waste generated is low-level waste. The Laboratory has written procedures to manage these radioactive materials.

\subsection{Property Release}

In accordance with the Secretary of Energy's memorandum, dated July 13, 2000, which suspended the unrestricted release for recycling of metal from radiological areas, as defined by 10 CFR 835.2, within DOE facilities, the Laboratory will either stock pile metals that could be recycled and wait for further guidance or dispose as radioactive waste, or release the item if it can be safely used for it's originally intended purpose.

\subsection{Radiation Emissions and Doses}

There were no point source releases from the Ames Laboratory complex in 2005. Diffuse source emissions were limited to low-level waste activities and renovation activities. Emissions from these activities were minimized or eliminated by engineering devices/structures, when necessary (e.g.. containment cells with HEPA filtration).

Using the guidance in 40 CFR 61.94, the annual radionuclide NESHAPS report was prepared. According to the guidance, and based on the isotope inventory in curies per year used at the Laboratory, air emissions were not required to be monitored. IDNR and IDPH do not require permits or monitoring for laboratory fume hoods under Chapter 20 IAC 567 22.1(2) (1). However, Appendix D to 40 CFR Part 61 does provide a method for estimating the radionuclide emissions for a year, for reporting purposes, based on the amount of radionuclides in curies used at a facility. The required parameters were used to calculate potential dose equivalent to the public due to estimated radionuclide emissions from the Laboratory (See correspondences in APPENDIX B).

\subsection{Unplanned Releases}

There were no unplanned or accidental radiological releases from Ames Laboratory in 2005. 


\subsection{Environmental Monitoring}

Liquid aqueous waste (laundry machine water), is no longer generated at the Waste Handling Facility (WHF). The WHF is slated for demolition in 2006. The WHF is located one mile northwest of ISU's main campus near the Applied Science Complex (ASC). (See WebPages www.external.ameslab.gov/common/amesmap.html. Click on lowa State University Campus Map).

Ames Laboratory performed no sampling of storm or sanitary sewer water in 2005 . The City of Ames samples twice each year and ISU (permittee) samples quarterly. The Chemical Disposal Site ground water was sampled. Section 7.0 discusses groundwater.

\subsection{Areas of Concern}

Ames Laboratory, DOE, and ISU have addressed all known contaminated sites in or near the City of Ames. There are no known areas of concern.

\subsubsection{Chemical Disposal Site (CDS)}

The CDS is a small former chemical burial site, located on ISU property near the Applied Sciences Complex (ASC), which was used from 1957-1966 for disposal of hazardous waste and waste from thorium and uranium production. The materials were buried according to standard practice at the time.

A Phase I Remedial Investigation (RI) report was conducted for the CDS in 1992-1993. A source removal was done during the fall of 1994, with final waste shipments completed in March 1995. The Phase II fieldwork was done in 1995 and 1996, including an ecological study. The 1996 network of 15 monitoring wells was installed in April 1995. Groundwater samples were collected for the Phase II RI in August and October 1995 and in January and April 1996. The samples were analyzed for 23 different parameters. Uranium and volatile contamination were detected in the wells closest to the excavated area. A Phase II RI final draft report was issued on July 24, 1996. A draft Focussed Feasibility Study and a draft Proposed Plan were issued concurrently with the RI report.

A public meeting was held to discuss the documents and future plans for the site. To address comments, a draft Responsiveness Summary was issued on December 5 , 1996. ISU conducted a "site characterization" in spring 1997, as advised by the IDPH.

In March 1999, the Department of Energy issued an Assistance Grant to lowa State University for continued groundwater monitoring through March of 2002 and for proper closure of the monitoring wells associated with the former Chemical Disposal Site (CDS). The site was cleared by the regulators. Data from Table 5.7-1 indicates there is no threat to Squaw Creek or the public water supply. ISU will continue to monitor four wells for an indefinite period of time. All other wells have been abandoned (See correspondences in APPENDIX A.) 
Table 5.7-1

\section{Chemical Disposal Site Groundwater Analysis}

Gross Alpha

Gross Beta

\begin{tabular}{|c|c|c|c|c|c|c|c|c|c|c|c|c|c|}
\hline Well & Location & June 00 & April 01 & May 02 & June 03 & Aug 04 & Aug 05 & June 00 & April 01 & May 02 & June 03 & Aug 04 & Aug 05 \\
\hline $4 \mathrm{~A}$ & Background Well & $<7.0$ & 3.5 & $<6.0$ & $<2.40$ & $<4.53$ & $<6.13$ & $<10.0$ & $<3.0$ & $<3.0$ & 5.80 & 6.01 & $<4.95$ \\
\hline $4 \mathrm{~B}$ & Background Well & $<8.8$ & $<3.0$ & $<5.0$ & $<2.55$ & $<4.24$ & $<5.38$ & $<14.0$ & 5.6 & 18.0 & 4.18 & 5.21 & 6.28 \\
\hline Davidson Hall & Background Well & $<8.0$ & $<4.0$ & $<7.0$ & - & - & - & $<4.0$ & $<4.0$ & $<4.0$ & - & - & - \\
\hline Lynch Farm & Background Well & $<10$ & $<4.0$ & 7.8 & - & - & - & $<9.0$ & 13.0 & 20.0 & - & - & - \\
\hline Beef Nutrition & Background Well & $<9.0$ & $<4.0$ & $<7.0$ & $<3.68$ & - & - & 16.0 & 6.2 & 9.8 & 9.62 & & - \\
\hline Skunk & Surface Water & - & - & $<6.0$ & - & - & - & - & - & 7.6 & - & - & - \\
\hline Squaw Creek & Surface Water & $<6.0$ & 4.0 & - & $<2.97$ & - & - & $<4.0$ & 4.1 & - & 6.39 & - & - \\
\hline SW 1 & Surface Water & - & $<6.0$ & - & $<2.99$ & - & - & - & 6.1 & - & 13.0 & - & - \\
\hline SW 2 & Surface Water & - & $<4.0$ & - & $<2.43$ & - & - & - & 11.0 & - & 12.7 & - & - \\
\hline SW 3 & Surface Water & $<4.0$ & $<5.0$ & $<9.0$ & $<4.06$ & - & - & $<5.0$ & 5.5 & 7.1 & 9.25 & - & - \\
\hline $8 \mathrm{~A}$ & Site Well & $<10$ & $<3.0$ & $<7.0$ & $<2.65$ & $<4.50$ & $<6.73$ & 11.0 & 6.3 & 6.3 & 6.76 & 7.43 & 4.57 \\
\hline $8 B$ & Site Well & $<10$ & $<4.0$ & $<8.0$ & $<4.32$ & $<5.66$ & $<7.12$ & 12.0 & 4.4 & 7.9 & 6.19 & 4.99 & 4.41 \\
\hline $7 \mathrm{~A}$ & Site Well & - & 17.0 & $<10$ & $<3.63$ & - & - & - & 4.9 & 18 & 7.61 & - & - \\
\hline $7 \mathrm{~B}$ & Site Well & - & $<10.0$ & $<10$ & $<11.9$ & - & - & - & 14.0 & 30 & 11.8 & - & - \\
\hline $10 \mathrm{~A}$ & Site Well & 900 & 110 & 710 & 91.90 & - & - & 2700 & 140 & 700 & 153 & - & - \\
\hline 10A FD & Site Well & 830 & 260 & 520 & 229 & - & - & 960 & 260 & 680 & 394 & - & - \\
\hline 10B & Site Well & 600 & 1000 & 520 & 78.1 & - & - & 1300 & 500 & 710 & 179 & - & - \\
\hline $11 \mathrm{~A}$ & Site Well & - & 710 & - & 47.8 & - & - & - & 900 & - & 98.6 & - & - \\
\hline $11 B$ & Site Well & $<1.0$ & $<6.0$ & $<9.0$ & $<5.67$ & - & - & 12.0 & 8.0 & 12.0 & 9.26 & - & - \\
\hline
\end{tabular}

Results are in $\mathrm{pCi} / \mathrm{L}$. 


\subsubsection{Inactive Waste Sites (IWS)}

The regulators have released a total of 12 IWS's (See Correspondence in Appendix C). The status of the sites released follows.

\section{Site}

Old Sewage Plant

Grand Avenue Underpass

Ames Municipal Cemetery

Applied Sciences Complex

Block House

Little Ankeny Debris

Annex I

Annex II

Ames Municipal Airport

Chemical Disposal Site

Former lowa State College Dump Site

Fire Service Institute Training Area
Release Status

Unrestricted use

Unrestricted use

Unrestricted use

Unrestricted use

Unrestricted use

Unrestricted use

Approved for current use

Approved for current use

Approved for current use

Unrestricted use

Unrestricted use

Unrestricted use
Date Released

1995

1996

1996

1996

1996

1996

1996

1996

1996

1998

2001

2002

\subsubsection{Former lowa State College Dump Site}

Another area of concern was a five-acre tract at $13^{\text {th }}$ Street and Stange Road in Ames. It has since been released. (See WebPages www.external.ameslab.gov/common/amesmap.html. Click on lowa State University Campus Map). Manhattan Project and Ames Laboratory wastes were disposed there in the early 1940's. In 1946, 250 tons of uranium extraction wastes were removed from the site for processing.

It was determined the radiological waste portion of the site would be sampled to determine if it posed a threat to human health or the environment. Sampling was conducted in August 1995. The samples were below action levels for thorium, uranium and their decay products, indicating no threat to human health or the environment. DOE sent results to IDPH in September 1995, indicating that DOE considered the radiological investigation closed. IDPH determined the site met the radiological standard for unrestricted use (See September 17, 2001 correspondence in Appendix C).

\subsubsection{Fire Service Institute Training Area}

This site is on the ISU campus, and under ISU control and responsibility. It is on the northeast corner of the intersection of Haber Road and the Chicago Northwestern Railroad. (See WebPages www.external.ameslab.gov/common/amesmap.html. Click on lowa State University Campus Map). ISU conducted a radiological survey of the site in April 1995 and found seven small areas of activity above background levels. The University fenced those areas to minimize human contact. Soil samples collected in July and October 1995 detected some thorium contamination. The sample ranged from 14.9 to $662.9 \mathrm{pCi} / \mathrm{g}$ Th-232. Limited non-radiological sampling was also conducted. The samples were analyzed for TCLP metals, 
volatiles and pesticides. The results were within the regulatory limits. ISU issued a summary of their site sampling activities on November 22, 1996.

Chase Environmental Group (CEG), Inc, under contract with ISU, conducted radiological surveys and soil sampling on November 6-11, 1997. The survey was performed to determine the radionuclides involved, and to determine the depth of contamination. The Survey Report was published May 7, 1998. CEG finished remediation activities in August 1999. The site met clean-up standards set by the lowa Department of Public Health (IDPH). As a result of the remedial activity, 250 B- 25 boxes representing approximately 24,000 cubic feet of thoriumcontaminated soil was generated. In December of 2000, 225 B-25 boxes were shipped to Texas Ecologist, Inc. in Robstown, Texas, for disposal. The waste was shipped as nonhazardous industrial waste (soil contained less than $51 \mathrm{pCi} / \mathrm{gm}$ thorium). The remaining boxes (25) were shipped off site in December 2002 to Envirocare of Utah. On February 26, 2002 the IDPH concurred with ISU that the site met the standards for "unrestricted" use (See Appendix C). Due to the possibility of some of the thorium contamination being linked to former Atomic Energy Commission activities at Ames Laboratory, DOE was implicated as one of the potential responsible parties. DOE issued a grant to ISU for $\$ 350,000$ in September 2000 for the clean up and disposal of contaminated soil from the Fire Service Institute Training Area.

\subsubsection{Waste Handling Facility (WHF)}

The WHF is located one mile northwest of ISU's main campus near the Applied Sciences Complex (ASC). (See WebPages www.external.ameslab.gov/common/amesmap.html. Click on lowa State University Campus Map). The WHF was originally built to process waste from the Laboratory's research reactor. The reactor was decommissioned in 1978. Since that time the WHF has been used to store and process radiological contaminated material for disposal. Maintaining the WHF and the energy usage required to heat and cool the building is a cost burden. Therefore, the WHF is slated to be demolished in 2006. Currently, the building is being surveyed for radiological and hazardous substances. All identified contaminants will be removed prior to demolition, according to all applicable state/federal regulations and DOE guidelines. 


\subsection{ENVIRONMENTAL NON-RADIOLOGICAL PROGRAM}

\subsection{National Pollutant Discharge Elimination System (NPDES) Data}

Ames Laboratory does not have or need any NPDES permits since there are no direct sanitary discharges or surface runoff to the environment. The Laboratory discharges all liquid wastes to the ISU sanitary sewer system, which discharges into the City of Ames sanitary sewer system. The Laboratory's wastewater is included in the university's pretreatment agreement with the City of Ames. Since the DOE buildings are on ISU land, ISU holds any necessary storm water permits (See section 3.7).

\subsection{Other Emissions Monitoring}

Ames Laboratory did not have any activities in 2005 that required monitoring.

\subsection{Continuous Release Reporting}

Ames Laboratory had no continuous release sources in 2005.

\subsection{Environmental Occurrences}

There were no environmental occurrences in 2005.

\subsection{SARA Title III Reporting Requirements}

The Laboratory reviews all chemical purchases and performs a year end review to verify the quantities of chemicals stored on its site. The Laboratory did not store any chemicals at or above the EPCRA threshold limits in 2005. The Laboratory was in compliance with Executive Order 13148 (Federal Compliance with Right-to-Know Laws and Pollution Prevention Requirements) in 2005. 


\subsection{GROUNDWATER MONITORING AND PROTECTION}

The Laboratory does not routinely monitor groundwater. As the land owner, ISU monitors the former Chemical Disposal Site as part of an agreement with the lowa Department of Public Health (See section 5.7.1). There are no current Ames Laboratory activities that pose a hazard to groundwater or surface water. The Laboratory has no underground storage tanks. Three DOE owned monitoring wells were abandoned June 2005.

Currently, lowa State University is not required to monitor groundwater on the main campus.

The CDS was monitored as prescribed by the IDNR and IDPH. Only the CDS wells were sampled in 2005 (See table 5-7.1).

\subsection{QUALITY ASSURANCE PROGRAMS}

Radioactive sources and solutions that are used for calibration of radiation-detection instrumentation are obtained with quantitative calibration directly traceable to the National Institute of Standards and Technology. Ames Laboratory's quality assurance effort relied on established U.S. EPA, IDNR, IDPH, and DOE regulations, standards and methods. This applies to both radioactive and non-radioactive environmental sampling and analyses.

Ames Laboratory's air quality assurance procedure consists of maintaining an exhaust hood inventory, maintaining a radiological material balance, tracking chemicals, and waste collection and management. These measures determine if the Laboratory has a source in need of monitoring or permitting, in accordance with IDNR guidance. The Laboratory used the COMPLY modeling program to produce the annual NESHAP report (See Appendix B).

The Safe Drinking Water Act established drinking water quality standards, wellhead protection requirements, monitoring requirements, treatment standards, and the regulation of underground injection activities. Drinking water for Ames Laboratory is supplied by ISU, which obtains its water from the City of Ames public water system. The Laboratory has a policy for monitoring lead. Potable water was sampled in 2005. (See Table 3.8-1 for analytical results).

Ames Laboratory did not have any regulated point source discharges in 2005 . Neither the Laboratory nor ISU has a NPDES wastewater permit. The City of Ames has a NPDES permit. The City of Ames has an agreement for wastewater pre-treatment with ISU, which includes Ames Laboratory wastewater. Both the City of Ames and the University sampled ISU wastewater effluent using EPA protocols and methods in 2005. Since existing DOE buildings are on land leased from ISU, the ISU storm-water permit covers Ames Laboratory activities.

Sampling methodologies, containerization, and analyses complied with EPA and receiving facility standards. Sample shipments and handling complied with standards of the U.S. Department of Transportation and the International Air Transporters Association. 
Line management directs Laboratory Group/Section leaders to be responsible for assuring that measuring and test equipment is of proper type, accuracy, and tolerance to accomplish the specified requirements.

In 2005, the Laboratory followed its Readiness Review (RR) Procedure for new or significantly modified research activities. This procedure is for risk identification, categorization, and ES\&H review of activities. Another purpose of the RR is to prevent and/or control releases of hazardous materials to the environment. It was developed to ensure that an appropriate level of rigor, commensurate to the risk associated with an activity's hazards, is applied to the activity's ES\&H review. Forty readiness reviews were approved in 2005. Approved activities are reviewed every five years. 


\subsection{REFERENCES}

1. Ames City Manager's Office, demographic information.

2. Ames Laboratory Site Environmental Reports.

3. City of Ames and ISU Pretreatment Agreements \#3593-3 and \#4093-3.

4. DOE Order 231.1, "Environment, Safety and Health Reporting."

5. DOE Order 5400.5, "Radiation Protection of the Public and the Environment."

6. DOE Order 474.1A, "Control and Accountability of Nuclear Materials."

7. Executive Order 13148, "Greening the Government Through Leadership in Environmental Management."

8. Executive Order 13101, "Federal Acquisition, Recycling and Waste Prevention."

9. Characterization Report for the Ames Laboratory Chemical Disposal Site, lowa Sate University, September 1998.

10. IATA Dangerous Goods Regulations

11. Iowa Administration Code, Rule 567, Chapters 20-24 and 28, "Air Quality."

12. Iowa Administration Code, Rule 567, Chapter 60, "Wastewater Treatment and Disposal: Definitions, Rules of Practice."

13. Iowa Administration Code, Rule 567, Chapter 61, "Water Quality Standards."

14. Iowa Administration Code, Rule 567, Chapter 100, 101, 109, 118, 119, "Solid Waste Management and Disposal."

15. Iowa Administration Code, Rule 567, Chapter 131, "Notification of Hazardous Conditions."

16. Iowa Administration Code, Rule 567, Chapter 133, "Determining Cleanup Actions and Responsible Parties."

17. Iowa Administration Code, Rule 567, Chapter 140 and 141, "Hazardous Waste."

18. 10 CFR Part 1021, "National Environmental Policy Act Implementation Procedures."

19. 10 CFR Part 835, "Occupational Radiation Protection."

20. 29 CFR Part 1910.120, "Hazardous Waste Operations and Emergency Response." 
21. 40 CFR Part 63, "National Emission Standards for Hazardous Air Pollutants for Source Categories."

22. 40 CFR Part 82, "Protection of Stratospheric Ozone."

23. 40 CFR Part 112, "Oil Prevention; Spill Prevention, Controls and Countermeasures."

24. 40 CFR Part 131, "Water Quality Standards."

25. 40 CFR Part 141, "National Primary Drinking Water Regulations."

26. 40 CFR Parts 260-264 (subpart S), 265 and 268, "Hazardous Waste Implementing Rules."

27. 40 CFR Part 279, "Standards for the Management of Used Oil."

28. 40 CFR Part 300, "National Oil and Hazardous Substances Pollution Contingency Plan."

29. 40 CFR Part 302, "Designation, Reportable Quantities and Notification."

30. 40 CFR Part 355, "Emergency Planning and Notification."

31. 40 CFR Part 761, "Polychlorinated Biphenyls (PCBs) Manufacturing, Processing Distribution in Commerence, and Use Prohibitions."

32. Consent Agreement and Consent Order, executed February $27^{\text {th }}, 1996$. 


\subsection{LIST OF ACRONYMS}

ASC: Applied Sciences Complex of lowa State University.

ALCATS: Ames Laboratory Corrective Action Tracking System.

Bq: Becquerel, one disintegration per second.

CAA: Clean Air Act and Amendments.

CAG: Community Advisory Group for Ames Laboratory environmental activities.

CDS: Chemical Disposal Site

CERCLA: Comprehensive Environmental Response, Compensation and Liability Act.

CESQG: conditionally exempt small quantity generator.

CFR: Code of Federal Regulations.

CG: concentration guide, DOE derived.

CH: Chicago Operations Office of the U.S. Department of Energy.

Ci: Curie, 3.7E10 disintegration's per second.

CWA: Clean Water Act.

CX: categorical exclusion, a class of activities determined to have no environmental impact.

DOE: U.S. Department of Energy.

EA: environmental assessment.

EIS: environmental impact statement.

EMR: environmental management review.

EMS: environmental management system.

EPA: U.S. Environmental Protection Agency.

EPCRA: Emergency Planning and Community Right to Know Act.

ESA: Endangered Species Act.

ESH\&A: Environment, Safety, Health and Assurance office of Ames Laboratory. 
FFCA: Federal Facilities Compliance Act.

FIFRA: Federal Insecticide, Fungicide and Rodenticide Act.

FS: feasibility study.

FSP: field sampling plan.

g: grams

GOCO: a government owned, contractor operated facility.

HEPA: high efficiency particulate air, a filter element or filtration system.

HQ: Headquarters of U.S. Department of Energy.

IAC: Iowa Administration Code.

IDNR: lowa Department of Natural Resources.

IDPH: lowa Department of Public Health.

IPRT: Institute for Physical Research and Technology, ISU.

ISMS: Integrated Safety Management System.

ISU: lowa State University.

IWS: inactive waste site.

LDR: land disposal restriction.

LQG: large quantity generator.

MCL: maximum contaminant level.

mg/L: milligrams per liter; equivalent to ppm.

mrem: millirem.

mSv: millisievert, $10^{-3}$ Sieverts.

NEPA: National Environmental Policy Act.

NESHAP: National Emission Standards for Hazardous Air Pollutants.

NHPA: National Historic Preservation Act. 
NOV: notice of violation.

NPDES: National Pollutant Discharge Elimination System.

NRC: Nuclear Regulatory Commission.

ODS: ozone depleting substance.

PCB: polychlorinated biphenyls.

pCi: picocurie, $10^{-12}$ Curies.

PIDS: performance indicator database system.

QA: quality assurance.

QAP: Quality Assessment Program, DOE.

RCRA: Resource Conservation Recovery Act.

Rem: Roentgen equivalent man, radiation dose.

RESRAD: residual radiation model for sites.

RI: remedial investigation.

RPP: Radiological Protection Plan, for Ames Laboratory.

SARA: Superfund Amendments and Reauthorization Act.

SDWA: Safe Drinking Water Act.

SER: Site Environmental Report.

TASF: Technical and Administrative Support Facility, the Ames Laboratory office building.

TCLP: Toxicity Characteristic Leaching Procedure

TPQ: threshold-planning quantity.

TRU: transuranic waste.

TSCA: Toxic Substances Control Act.

WAS: work authorization system of Ames Laboratory. 


\subsection{REPORT DISTRIBUTION}

\section{Organization}

Ms. Roxanne Purucker, Manager

Ames Site Office

9800 South Cass Avenue

Argonne, IL 60439

Roxanne.Purucker@ch.doe.gov

Mr. Rollow Thomas, Director

Office of Worker Advocacy

Department of Energy, EH-8/FORS

1000 Independence Avenue, S.W.

Washington, DC 20585

Tom.rollow@hq.doe.gov

Mr. David Stadler, Deputy Assistant Secretary, Oversight

Department of Energy, EH-2/270

19901 Germantown Road

Germantown, MD 208874-1290

David.stadler@eh.doe.gov

Mr. Peter Rosen, Associate Director

Office of High Energy and Nuclear Physics

Department of Energy, SC-20/GTN

19901 Germantown Road

Germantown, MD 208874-1290

Peter.rosen@science.doe.gov

Ms. Van Nguyen, General Engineer

Environment, Safety and Health Division

Department of Energy, SC-83/GTN

19901 Germantown Road

Germantown, MD 208874-1290

Van.nguyen@science.doe.gov

Mr. Justin Zamirowski, Supervisory General Engineer

Safety and Technical Services

DOE Chicago Office, Bldg 201

9800 South Cass Avenue

Argonne, IL 60439

Justin.Zamirowski@ch.doe.gov 
Mr. Steven Silbergleid, Chief Counsel

Legal Services Group

DOE Chicago Office

9800 South Cass Avenue

Argonne, IL 60439

Steven.silbergleid@ch.doe.gov

Mr. Alan Handwerker, Supervisory General Attorney

Office of General Law

DOE Chicago Office

9800 South Cass Avenue

Argonne, IL 60439

Alan.handwerker@ch.doe.gov

Mr. Glenn Podonsky, Director

Office of independent Oversight \& Performance

Department of Energy, C-403

19901 Germantown Road

Germantown, MD 20870

Glenn.podonsky@hq.doe.gov

Mr. Richard Day, General Engineer

Department of Energy

Office of Price-Anderson Enforcement, EH-10/270CC

19901 Germantown Road

Germantown, MD 20870

Richard.day@hq.doe.gov

Mr. Ross Natoli, Environmental Protection Specialist

Department of Energy

Air, Water and Radiation Division, EH-412/FORSTL

1000 Independence, SW

Washington, DC 20585

Ross.natoli@hq.doe.gov

Mr. Walter L. Warnick, Director

Office of Scientific and Technical Information

U.S. Department of Energy, OSTI/GTN

175 Oak Ridge Turnpike

P.O. Box 62

Oak Ridge, TN 37831

walter.warnick@science.doe.gov 
Mr. Gustavo Vazquez, Environmental Engineer

Office of Air, Water and Radiation Division, EH-41/Forrestal Building

U.S. Department of Energy

1000 Independence Ave., S.W.

Washington, DC 20585

gustavo.vazquez@eh.doe.gov

Ms. Kate Sordelet

Ames Laboratory Technical Information

lowa State University

125 Spedding Hall

Ames, IA 50011-3400

sordeletk@iastate.edu

Mr. Gene Gunn, Chief

FFSESUPR

USEPA Region VII

901 North Fifth Street

Kansas City, KS 66101

Gunn.gene@epa.gov

Mr. Craig Bernstein

FFSESUPR

EPA, Region VII

901 North Fifth Street

Kansas City, KS 66101

Bernstein.craig@epa.gov

Mr. William A. Spratlin

Director, Air and Toxics Division

USEPA Region VII

901 North $5^{\text {th }}$ Street

Kansas City, KS 66101

Spratlin.william@epa.gov

Mr. Don Flater

Bureau of Radiological Health

lowa Department of Public Health

Lucas State Office Building

Des Moines, IA 50319-0075

Mr. Scott Vander Hart

DNR Environmental Services Administration

502 East 9th Street, Wallace Building

Des Moines, IA 50319-0034 


\author{
Dr. David Inyang, Director \\ Environmental Health and Safety \\ 118 Agronomy Laboratory \\ lowa State University \\ Ames, IA 50011 \\ Adinyan@iastate.edu \\ Senator Charles Grassley \\ United States Senate \\ Washington, DC 20510-0001 \\ http://grassley.senate.gov/contact/contact.cfm \\ Senator Tom Harkin \\ United States Senate \\ Washington, D.C. 20510 \\ http://harkin.senate.gov/contact/contact.cfm \\ Representative Tom Latham \\ United States House of Representatives \\ Washington, DC 20515 \\ Tom.latham@mail.house.gov \\ Senator Herman Quirmabach \\ Senate Chambers \\ State House \\ Des Moines, IA 50319-0001 \\ Herman.quirmbach@legis.state.ia.us \\ State Representative Beth Wessel-Kroeschell \\ State Capital \\ Des Moines, IA 50319 \\ Beth.wessel-kroeschell@legis.state.ia.us
}

\title{
Ames Laboratory Community Advisory Group:
}

Mr. Robert (Toby) Ewing

608 Brookridge Avenue

Ames, IA 50010

Ms. Jean Day Lassila

3605 Ross Road

Ames, IA 50014

Mr. Joe Lynch

RR6, Box 26

Ames, IA 50014 
Stacy Joiner

1029 Florida Avenue

Ames, IA 50014-3069

\section{Ames Laboratory Management and Discipline Specialists:}

Director, Dr. Tom Barton

Barton@ameslab.gov

Deputy Director, Dr. Bruce Harmon

Harmon@ameslab.gov

Chief Operations Officer, Mr. Mark Murphy

Murphy@ameslab.gov

Division Director S \& T, Dr. Alan Goldman

Goldman@ameslab.gov

Information Officer, Mr. Steve Karsjen

Karsjen@ameslab.gov

ESH\&A Manager, Mr. Tom Wessels

Wessels@ameslab.gov

Radiation Safety Officer, Mr. Mike McGuigan

mcguigan@ameslab.gov

Industrial Hygiene, Mr. James Withers, $\mathrm{ClH}$

Withers@ameslab.gov

Fire and Plant Protection, Mr. G.P. Jones

Jonesgp@ameslab.gov

Industrial Safety, Mr. Shawn Nelson

Nelsons@ameslab.gov

Environmental Specialist, Mr. Dan Kayser

Kayser@ameslab.gov 


\section{APPENDIX A}

\section{Chemical Disposal Site (CDS) Correspondences}

1) Letter to IDPH requesting release of the CDS, September 30, 1998.

2) Letter from IDPH granting "unrestricted" release of the CDS, October 15, 1998.

3) Letter from IDPH to Edward J. Stanek, II, Ph.D., status of CDS, October 16, 1998.

4) Letter from ISU to DOE-Ames Group, October 22, 1998. 


\section{IOWA STATE UNIVERSITY \\ OF SCIENCE AND TECHNOLOGY}

September 30, 1998

Mr. Donald A. Flater

Chief, Bureau of Radiological Health

Iowa Department of Public Health

Lucas State Office Building

Des Moines, IA 50319-0075

Dear Mr. Flater:
Environmental Health and Safety

118 Agronomy Lab

Ames, lowa 50011-3200

515 294-5359

FAX 515 294-9357

Enclosed are 3 copies of the "Characterization Report for the Ames Laboratory Chemical Disposal Site - Iowa State University", dated September, 1998. This report reflects the latest work at the Chemical Disposal Site (CDS) which evolved from our meeting with IDPH on August 28, 1998. At that meeting we made the decision to remove any remaining surface soil radiation levels that were more than twice background. That work was accomplished and the affected areas were resurveyed on 9-1-98 to confirm that they were at background levels (IDPH personnel were present for the survey).

As a result of the above efforts, we believe the CDS site now meets the criteria for unrestricted release. Moreover, the Jones/McMahon study of groundwater movement at the CDS has been released, and confirms the assessment that the underground water plume has reached a steady state at the site. The down-gradient concentrations are expected to decrease over the coming years with the judgement that there is no potential threat to either Squaw Creek or the public water supply.

Therefore, after IDPH review of the enclosed report, lowa State University is requesting consideration of the following action:

1. Release of the CDS on an unrestricted basis.

2. Reduce the groundwater sampling frequency to once per year for the remainder of the 5 year schedule.

3. Allow closure of monitoring wells $\mathrm{MW}-9 \mathrm{~A}$ and $\mathrm{MW}-9 \mathrm{~B}$ because of their deteriorating condition. (This has already been verbally granted by $\mathrm{DPH}$ but we would appreciate having this in writing).

We appreciate the assistance and cooperation of the IDPH on the CDS project and look forward to a successful completion. We have enclosed enough copies of the "CDS Characterization Report" so you can provide them to the EPA offices involved in this project. When we hear back from the $\mathrm{DPH}$, we will provide appropriate copies to the Ames Lab, DOE and IDNR.

Sincerely,

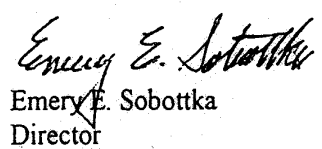

enclosure

cc Warren Madden

Paul Tanaka

H:IGROUPSIADMINICDS Characterization Report Letter September 30.doc 


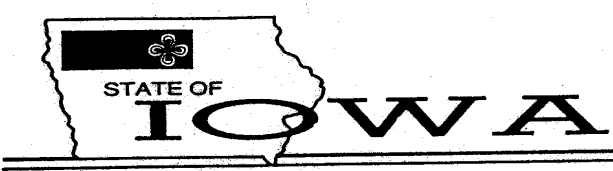

TERRY E. BRANSTAD, GOVERNOR

DEPARTMENT OF PUBLIC HEALTH

CHRISTOPHER G. ATCHISON, DIRECTOR

October 15, 1998

Emery Sobottka

Iowa State University

118 Agronomy Laboratory

Ames, Iowa 50011-3200

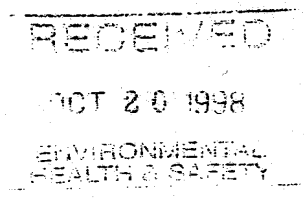

Dear Mr. Sobottka:

This correspondence refers to the "Characterization Report for the Ames Laboratory Chemical Disposal Site-Iowa State University:" You submitted that report to us under cover of your letter dated September 30, 1998.

We have read and reviewed the report and analyzed the data. We agree with your conclusions and recommendations.

The site, known as the Ames Laboratory Chemical Disposal Site, meets the standards for unrestricted use. Additionally, we concur with your recommendation that the groundwater sampling frequency be reduced to annual. This sampling will continue until 2002.

If you have any questions or comments, please call Dan McGhee or me at (515)2817007.

Sincerely,

O

bonald A. Flater, Chief

Bureau of Radiological Health

J:Vramlchemdisplfinal report resp.doc

LUCAS STATE OFFICE BUILDING / 321 E. 12 TH ST. / DES MOINES, IOWA $50319-0075$ DEAF RELAY (HEARING OR SPEECH IMPAIRED) 1-800-735-2942/INTERNET: HTTP://IDPH.STATE.1A.US/

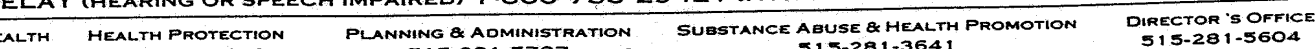

FAMILY \& COMM. HEALTH HEALTH PROTECTION PLANNINGQADMINISTRATION SUBSTANCEABUSE B HEALTH PROMOTION DIRECTOR'S OFFICE 


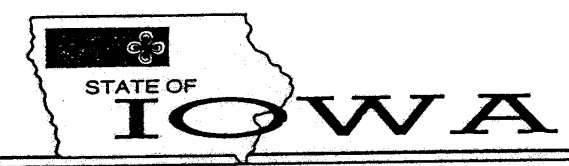

TERRY E BRANSTAD. GOVERNOR

October 16,1998

Edward J. Stanek, II, Ph.D.

2015 Grand Avenue

Des Moines, Iowa 50312

Dear Dr. Stanek:
DEPARTMENT OF PUBLIC HEALTH CHRISTOPHER G. ATCHISON, DIRECTOR

This correspondence refers to the chemical Disposal Site (CDS) in Ames, lowa. This area had been used as a disposal site by Ames Laboratory, a contractor for the U.S. Department of Energy (DOE). As you know, the DOE. remediated this site in 1994. They then published the results and made recommendations for the future use of the land.

The Iowa Code designates the Iowa Dept. of Public Health (IDPH) as the state's radiation control agency. Additionally, Iowa State University (ISU) holds an Iowa Radioactive Materials license. As a result, IDPH became involved, as an overseeing agency, with the CDS project in 1994.

In August 1996, and again in December 1997, IDPH went on record with DOE saying that it could neither agree with nor concur in the data or the recommendations as presented. Our stance was that a complete characterization of the CDS had not been conducted and that, therefore, the conclusions came from data that had no statistical relevance.

In the spring of 1997 ISU initiated a complete characterization study of the CDS. We have kept you apprised of the progress of that project.

On Friday, October 9, 1998, ISU submitted its final report. In that report, ISU concludes that the CDS meets the standards for unrestricted use and recommends that annual samples from the groundwater monitoring wells be continued, on an annual basis, until 2002 to confirm the results of the study. The U.S. Environmental Protection Agency accepts this monitoring regimen.

We have reviewed the ISU data and report. We agree with the conclusions and the recommendations. We have issued a letter to ISU stating that the CDS meets the standards for unrestricted use. That letter will also contain our concurrence to reduce the groundwater monitoring frequency to annually and to continue this monitoring until 2002.

LUSATATE OFFICE BUILING / 321 E 12 THST, DES MOINES. 1OWA 50319-0075 LUCAS STATE OFFICE BUILDING / 321 E. 12 TH ST. / DES MOINES. IOWA SO319-OOTS: 1 -800-735-2942/INTERNET: HTTP:/IDPTA.SA.US/

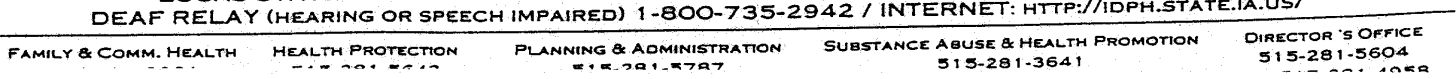


Page 2

Stanek, Edward

October 16, 1998

If you have any questions or comments, please do not hesitate to contact me.

Sincerely,

Smaed Gi Flater

Donald A. Flater, Chief

Bureau of Radiological Health

515-281-3478

515-242-6284-FAX

dflater@idph.state.ia.us

\section{$\mathrm{DAF} / \mathrm{r}$}

cc: Emery Sobottka, ISU

Joe Obr, IDNR

J:Lramichemdisplstanekefinal.doc 
IOWA STATE UNIVERSITY

OF SCIENCE AND TECHNOLOGY
Environmental Health and Safety 118 Agronomy Lab Ames, Iowa 50011-3200

515 294-5359

FAX 515 294-9357

October 22, 1998

Mr. James Buchar

Ames Group

Department of Energy

Chicago Operations Office

9800 South Cass Ave

Argonne, II 60439

Dear Mr. Buchar:

The additional sampling and testing that we have been conducting at the Ames Laboratory Chemical Disposal Site (CDS) has culminated in the Iowa Department of Public Health (IDPH) granting ISU unconditional release of the CDS site. In addition, the IDPH has also granted our request to reduce groundwater well water sampling frequency from one per quarter to once per year for the remainder of the sampling period (until year 2002). Enclosed are documents which describe CDS activities:

1. The final Characterization Report for the CDS.

2. A letter from ISU to IDPH (dated September 30, 1998) which requests unrestricted closure and reduces groundwater sampling frequency at the CDS.

3. Two letters from IDPH (dated October 15, 1998 and October 16, 1998) which grant ISU unrestricted release of the CDS and reduced groundwater sampling at the CDS until the year 2002 .

After you have had the opportunity to review these documents I would like to continue our discussion about coordinating a joint press release. A lot of people, departments, state and federal agencies, etc., have had a hand in completing this successful project and we may want to consider some recognition of that fact.

Sincerely,

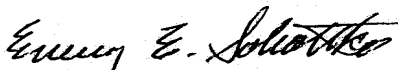

Emery). Sobottka

Director

enclosure

$\mathrm{cc}$

Tom Barton, Ames Lab

Tom Wessels, Ames Lab

Joe Obr, IDNR

Warren Madden (\#3 enclosure only)

Paul Tanaka (\#3 enclosure only) 


\section{APPENDIX B}

\section{Air Permit Correspondences}

1) Letter from IDNR exempting laboratory fume hoods from permitting, July 18, 1994.

2) Letter from Jacobs Engineering Group Inc. exempting graphics paint spray booth from permitting, July 16, 1997.

3) Letter from IDNR exempting graphite lathe hood exhaust from permitting, February 6, 1998.

4) U.S. Department of Energy Air Emissions Annual Report, Calendar Year 2005. 


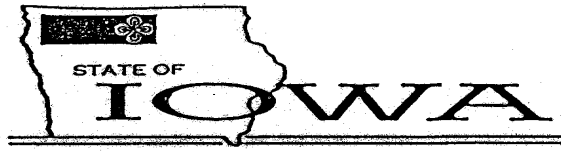

TERRY E. BRANSTAD, GOVERNOR

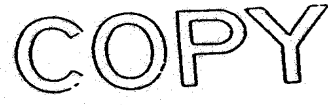

DEPARTMENT OF NATURAL RESOURCES

July 18,1994 :

Ms. Lowell K. Mathison:

CERTIFIED

Environment, Safety \& Health Group

Ames laboratory

lowa State University

115 Spedding

Ames, IA 50011

\section{Dear Mr. Mathison,}

This letter is to inform you that the 144 chemical fume hoods and associated 34 exhaust points described in your letters dated April 14th and June 28th of 1994 are exempted from both air construction permit and Title $V$ permitting provisions.

If you have any questions regarding the above, please call me at (515) 281-8852.

Sincerely,

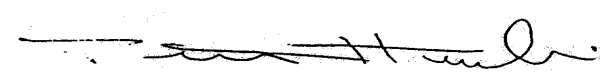

Peter Hamlin, chief

Air Quality Bureau 


\section{IF JACOBS ENGINEERING GROUP INC. \\ (C) \\ 8208 MELROSE DRIVE, SUITE 210 , LENEXA, KANSAS 66214 \\ TELEPHONE (913) 492-9218 • FAX (913) 492-6198}

July 16,1997

Mr. Walter P. Waters

Iowa State University

Ames Laboratory

G40 TASF

Ames, IA 50011

Mr. Waters,

Jacobs Engineering has been contracted by the Iowa Department of Natural Resources to review Iowa State University's application for an air construction permit for a paint spray booth (S23). The project number assigned is $96-456$.

According to 567 Iowa Administrative Code (IAC) 22.8 (1)c, the paint spray booth is exempt from the permitting process if more than one gallon per day but less than three gallons per day of spray material is sprayed. The emissions must be vented through a stack that is at least 22 feet tall and daily records of the material sprayed must be kept for eighteen (18) months from the date to which the records apply. In order formally be exempt from the permitting process, a written statement must be submitted according to 567 IAC 22.8(1)e which reads:

"I certify that all paint booths at the facility and listed below are in compliance with all applicable requirements of rule 567 IAC $22.8(1)$. I understand this equipment shall be deemed permitted under the terms of 567 IAC 22.8(1) only if all applicable requirements of 567 IAC 22.8(1) are met This certification is based on information and belief formed after reasonable inquiry; the statements and information in the document are true, accurate, and complete.'"

This certification must be signed by, for municipal, state, county, or other public facilities, the principal executive officer or the ranking elected official.

This certification must be submitted to:

Mr. Pete Hamlin, Air Quality Chief

Iowa Department of Natural Resources

7900 Hickman Road, Suite 1

Urbandale, IA 50322

Sincerely,

Babcua Supencuy

Barbara Seuferling

Jacobs Engineering Group, Inc

n:yroject12P09901/winwordisulexmpt.doc

$7 / 16 / 97$ 


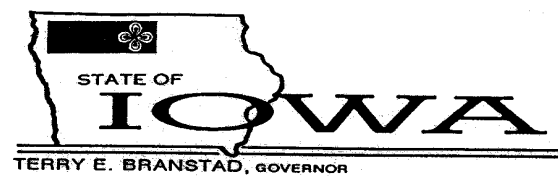

DEPARTMENT OF NATURAL RESOURCES
LARRY J. WILSON, DIRECTOA

\section{CERTIFIED MAIL}

February 6, 1998

ATTN: Walter P. Waters

Ames Laboratory

lowa State University

Ames, lowa 50011-3020

RE: Construction permit exemption request for graphite lathe hood exhaust Facility No. 85-01-057

Dear Mr. Waters:

Your request for a construction permit exemption for the above referenced source has been received. Based on the information you have provided your request has been approved. You should be aware that any exemption you qualify for does not establish any federally enforceable emission limits. This means that when determining applicability for the various programs you may be subject to, our bureau would assume the maximum potential emissions from this source.

If you have any questions, you may contact me at the address or telephone numbers listed below.

Sincerely,

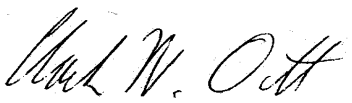

Clark W. Ott

Environmental Specialist - Compliance Assistance Section

Air Quality Bureau

515-281-4899

cc: FO5, w/ attachments 


\title{
U.S. Department of Energy Air Emissions Annual Report \\ Calendar Year 2005
}

\section{SECTION I}

\author{
Facility Information
}

Site Name: Ames Laboratory, Iowa State University

Operations Office: Chicago Operations

Address: 9800 South Cass Avenue

Argonne, IL 60439

Contact: Mike Saar Phone: 630-252-2245

Site Operator: Iowa State University

Site Address: G40 TASF, Iowa State University

Ames, IA 50011

Contact: Dan Kayser $\quad$ Phone: (515) 294-2153

\section{Site Description:}

The Ames Laboratory is located on the campus of Iowa State University (ISU) in Ames, Iowa. The Ames Laboratory is operated by ISU for the DOE under contract No. W-7405-ENG-82. There are nine buildings owned by the DOE. The Ames Laboratory conducts basic and intermediate applied research in physical, mathematical, and engineering sciences that underlie energy technologies and other areas of national importance. 


\section{SECTION II}

\section{Methods for Dose Assessment/Air Emissions Data}

Methods used for evaluating doses from the air emissions.

Very small amounts of radionuclides were used in CY 2005. Radionuclides were used in solution or in solid form; consequently there were no radioactive air emissions and no exposures to the general public. Values entered into the EPA's COMPLY model, were possession amounts and not release amounts. Based solely on possession quantities, Ames Laboratory met level 1 compliance criteria. Again, the potential for release and exposure to the public would be minimal and highly unlikely.

\section{CERTIFICATION}

I certify under penalty of law that I have personally examined and am familiar with the information submitted herein and based on my inquiry of those individuals immediately responsible for obtaining the information, I believe that the submitted information is true, accurate and complete. I am aware that there are significant penalties for submitting false information including the possibility of fine and imprisonment. (See, 18 U.S.C. 1001).

Name: _Tom Barton Title: Director, Ames Laboratory
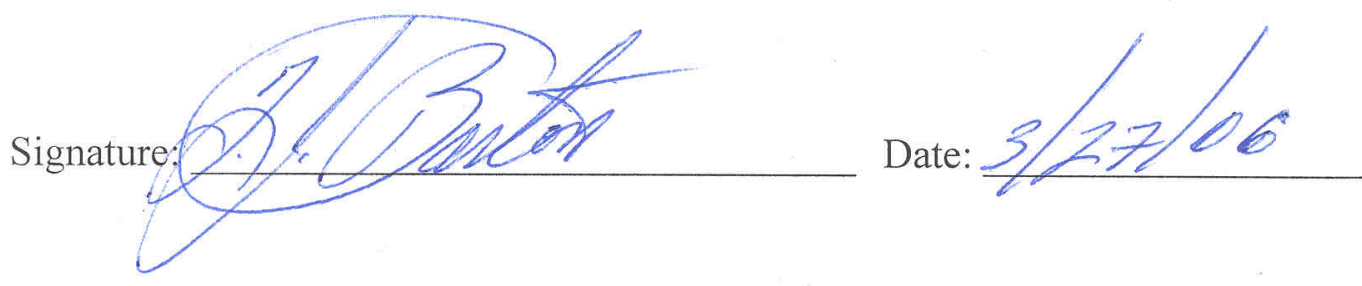


\section{APPENDIX C}

\section{Inactive Waste Sites Correspondences}

1) Letter from IDPH, Closure of nine waste sites, January 11, 1996.

2) Letter from DOE-CH, Regarding the lowa State College Dump Site, April 20, 1999.

3) Letter from IDPH, Closure of the Former lowa State College Dump Site, September 17, 2001.

4) Letter from IDPH, Closure of the Fire Service Institute Training Area, February 26, 2002. 


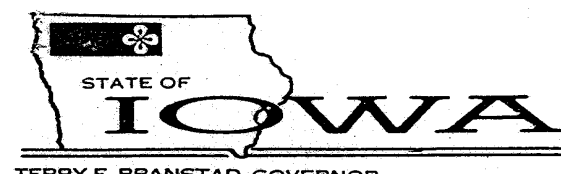

TERRY E. BRANSTAD, GOVERNOR

DEPARTMENT OF PUBLIC HEALTH CHRISTOPHER G. ATCHISON, DIRECTOR

January 11, 1996

Warren R. Madden

Vice President for Business and Finance

Iowa State University

125 Beardshear Hall

Ames, Iowa 50011-2038

Dear Mr. Madden:

Reference is made to your letter of January 5, 1996 in which you request our concurrence on the status of nine inactive waste sites which we possibly contaminated with radioactive materials as a result of the operation of Ames Laboratory as a DOE contractor in the past. Listed below are the sites by name and our conclusions as to the status of the site regarding closure.

1. Ames Old Waste Water Treatment Facility (WWTF): Met criteria for unrestricted use per Department letters to the city of Ames dated June 16, 1994 and February 17, 1995

2. Grand Avenue Under Pass: Based on the data provided by DOE, ISU and data collected by this Department this area meets the criteria for unrestricted use. In fact, there is information which indicates that this area never was subjected to the spreading of contaminated sludge from the WWTF.

3. Ames Municipal Cemetery: Based on the date provided by DOE, ISU and data collected by this Department this area meets the criteria for unrestricted use. In fact, there is information which indicates that this area never was subjected to the spreading of contaminated sludge from the WWTF.

4. Applied Science Center: Based on the data provided by DOE, ISU and data collected by this Department, this area meets the criteria for unrestricted use.

5. Block House Area : Based on the data provided by DOE, ISU and data collected by this Department, this area meets the criteria for unrestricted use.

6. Little Ankeny Debris Site: Based on the data provided by DOE, ISU and data collected by this Department, this area meets the criteria for unrestricted use.

7. Annex I: Based on the data provided by DOE, ISU and data collected by this Department, this area can be used as it is now, in perpetuity, without public health concerns. However, if the site is developed for any other purpose additional surveys or sampling will be necessary to confirm that if residual radioactive material exists it is not in amounts which could be of public health concern during the developmental process.

8. Annex $\Pi$ : : Based on the data provided by DOE, ISU and data collected by this Department, this area can be used as it is now, in perpetuity, without public health concerns. However, if the site is developed for any other purpose additional surveys or sampling will be necessary to confirm that if residual radioactive material exists it is not in amounts which could be of public health concern during the developmental process.

LUCAS STATE OFFICE BUILDING / DES MOINES. IOWA 50319-0075/515-281-5787 FAX \# (515) $281-4958$ / TDD-DEAF SERVICES \#(515) 242-6156 
Page 2

Madden, Warren $R$.

January 11, 1996

9. Ames Municipal Airport: Based on the data provided by DOE, ISU and data collected by this Department, this area can be used as it is now, in perpetuity, without public health concerns. However, if the site is developed for any other purpose additional surveys or sampling will be necessary to confirm that if residual radioactive material exists it is not in amounts which could be of public health concern during the developmental process.

Based on the above, it is my opinion that we concur with the University's decision to bring the nine sites to closure with the special provisions placed on Annex I, II and the Airport. I would like to take this opportunity to thank you, the ISU Staff and the Ames Laboratory Staff who have assisted in working through the long laborious process of reading the conclusions. We certainly look forward to working with all of you in the future. If you have question regarding the above, please do not hesitate to contact me.

\section{Sincerely,}

Trued l. Plate

Donald A. Flater, Chief

Bureau of Radiological Health

(515) 281-3478

cc:

E. Sobottka, ISU

Tom Newman, City of Ames

Dr. Tom Barton, Ames Laboratory

j:trad-adratmaddendoc 


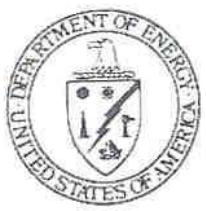

\section{Department of Energy \\ Chicago Operations Office \\ 9800 South Cass Avenue \\ Argonne, llinois 60439}

April 20, 1999

Dr. Aniefiok D. Inyang, Director

Environmental Health and Safety

118 Agronomy Laboratory

lowa State University

Ames, lowa 50011-3200

Dear Dr. Inyang:

\section{SUBJECT: IOWA STATE COLLEGE DUMP SITE}

References: 1. Letter, Taboas to Sobottka, dated January 30, 1996

2. Letter, Sobottka to Taboas, dated February 28, 1996

It has recently been brought to my attention that an old issue remains open relative to the lowa State's College Dump Site. As I can best determine the issue arose when the Department of Energy (DOE) in reviewing the University's “Review and Assessment of the Former lowa State College Dump Site" report provided some comments (Reference 1) for the University's consideration. As indicated in Reference 2, the University adopted most of the suggested changes. However, one statement as made regarding the availability of information about the disposal of beakers and containers at the site, which raised a concern with your predecessor. As can be seen from Reference 2, Mr. Sobottka was not aware of and did not have any evidence of anything other than uranium being disposed of at the site. Mr. Sobottka's letter requested that DOE make available any information we may have as to the origin or type of materials disposed of at the site and how we became aware of this information.

In trying to respond to this open issue, we have conducted a review internally of the statement previously made in our Reference 1 letter and we are not able to provide any documentation as requested. Our statement at the time was based on informal discussion with an Ames Laboratory employee (now retired) and a cursory review, over time, of some College Dump Site related documents, none of which were ever in our possession.

It is our position that without having any specific knowledge or records, other than as mentioned above, relative to the College Dump Site, we withdraw the comment in question and recommend that the report be finalized and the issue closed.

Enclosures:

Reference Letters

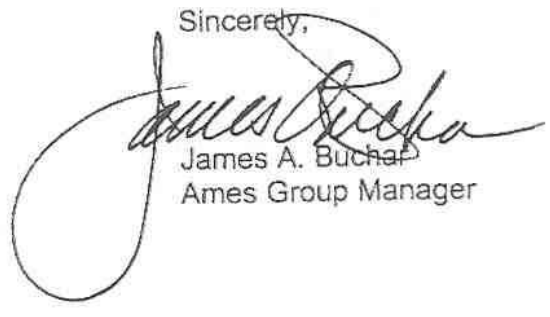

章 Fis

APR $2 \& \cdots$

ENVIRONMENTAL 


\section{STATE OF IOWA}

THOMAS J. VILSACK

GOVERNOR

SAILLY J. PEDERSON

L.T. GOVERNOR
DEPARTMENT OF PUBLIC HEALTH STEPHEN C. GLEASON. D.O., OIRECTOR

September 17, 2001

David Inyang, Ph.D., RSO

Iowa State University

118 Agronomy Lab.

Ames, Iowa 50011

Dear.Dr. Inyang:

This correspondence refers to your letter to me dated August 22, 2001. In that letter you enclosed a report entitled, "Review and Assessment of the Former Iowa State College Dump Site." This report detailed the actions taken to assess the radiological hazard at that site. Your letter requested that we review and comment on the report.

The report references and analyzes the results of soil sampling at the former dumpsite. We have reviewed this data and your conclusions. We agree that the data does show that the former lowa State College Dump Site meets the standards for unrestricted use.

We wish to remind you that our conclusions speak only to radiological standards and do not address heavy metals or organic compounds.

If you have any questions, please contact Dan McGhee at 515-725-0305 or me.

Sincerely,

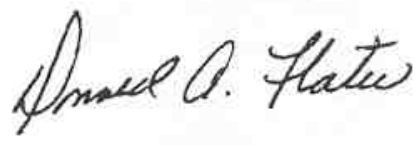

Donald A. Flater, Chief

Bureau of Radiological Health

(515) $281-3478$

401 SW 7 in STREET, SUITE D / DES MOINES, IOWA 50309-4611

DEAF RELAY (HEARING OR SPEECH IMPAIRED) 1-800-735-2942/ INTERNET: HTTP://IDPH.STATE.IA.US/

\begin{tabular}{ccc}
\hline DIRECTOR'S OFFICE & EXECUTIVE STAFF & DIV. OF AOMINISTRATION \& REGULATORY AFFAIRS \\
$515-281-5605$ & $515-281-5604$ & $515-281-5784$ \\
FAX/515-281-4958 & FAX $/ 515-281-4958$ & FAX $/ 515-281-4958$
\end{tabular}

DIV OF FAMILY \& COMMUNITY HEALTH DIV. OF HEALTH PROMOTION. PREVENTION \& AdOICTIVE BEHAVIORS 515-281-3931 
THOMAS J. VILSACK GOVERNOR

SALLY J. PEDERSON

LT. GOVERNOR

February 26, 2002

David Inyang, Ph.D.

Director, Environmental Health and Safety

Iowa State University

118 Agronomy Lab

Ames, Iowa 50011-3200

RE: Release of site for unrestricted use

Dear Dr. Inyang:

This correspondence refers to your letter, dated February 20,2002, to me. In that letter you transmitted the "Final Status Survey Report for Fire Service Institute Training Area Iowa State University." You also requested "the site be released for unrestricted use."

We have reviewed the report and agree with your conclusion that the site meets the standards for unrestricted use. You may refer to these standards in the Iowa Administrative Code 64140.29 (136C). We cannot, however, "release" this site because it was never restricted. We reiterate, though, that the data demonstrates compliance with unrestricted use.

If you have any questions, please contact Dan McGhee at 515-725-0305 or me.

Sincereiy,

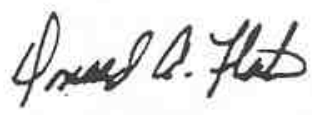

Donald A. Flater, Chief

Bureau of Radiological Health

515-281-3478

$515-725-0318$ - FAX

dflater@idph.state.ia.us

$\mathrm{DAF} / \mathrm{rk}$

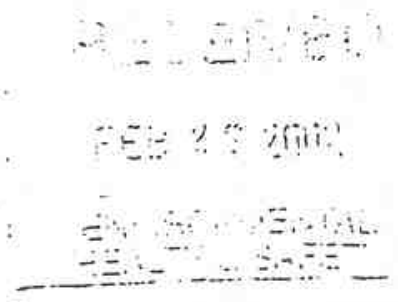

LUCAS STATE OFFICE BUILDING / 321 E. 12TH ST. / DES MOINES, 10 WA 50319-0075 DEAF RELAY (HEARING OR SPEECH IMPAIRED) 1-800-735-2942/INTERNET: HTTP://WWW.IDPH.STATE.IA.US/

$\begin{array}{ccc}\text { DIRECTOR'S OFFICE } & \text { DIV. OF AOMINISTRATION } & \text { DIV. OF COMMUNITY HEALTM } \\ 515-281-5605 & 515-281-5604 & \text { S15-281-6535 } \\ \text { FAX/515-281-4958 } & \text { FAX } 515-281-4958 & \text { FAXV15-242-6384 } \\ \text { DIV. OF HEALTH PROMOTION, PREVENTION \& AODICTIVE BEHAVIORS }\end{array}$

Div. of Health promotion, Prevention a aodictive Bemaviors 


\section{APPENDIX D}

\section{EPA Correspondences}

1) EPA letter (NOV's), April 6, 1999.

2) EPA e-mail status of CDS and WHF EPA ID Numbers, July 8, 2003.

3) DOE-CH letter approving Laboratory's EMS, December 21, 2005. 


\section{UNITED STATES ENVIRONMENTAL PROTECTION AGENCY}

\section{REGION VII \\ 726 MINNESOTA AVENUE \\ KANSAS CITY, KANSAS 66101}

APR 061999

\section{CERTIFIED MAIL}

Return Receipt Requested

Article Number: P 165405793

Dan Kayser, Environmental Specialist

Ames Laboratory

G40 TASF

Ames, IA 50011

Dear Mr. Kayser:

\section{RE: Ames Laboratory \#3}

Ames, IA

RCRA I.D. No. IA6890008950

On January 19-20, 1999, a representative of the U. S. Environmental Protection Agency (EPA) inspected your facility. The inspection was conducted under the authority of Section 3007 of the Resource Conservation and Recovery Act (RCRA). A copy of that inspection report is enclosev.

A Notice of Violation (NOV) was issued to your company during the inspection. I have reviewed your February 1, 1999, response to the NOV and determined that it adequately addresses the violations listed in the NOV. Therefore, no further submittals are required at this time. Please note that EPA reserves its right to pursue appropriate enforcement actions, including penalties, for violations discovered as a result of this inspection.

I would like to remind you that your facility is responsible for maintaining compliance with all applicable hazardous waste regulations. If there are any questions regarding this matter, please contact me at (913) 551-7136.

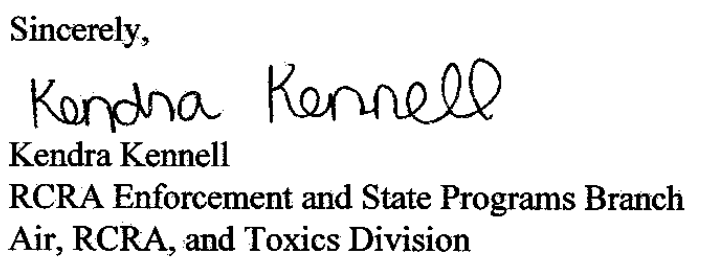

Enclosure

cc: Joseph Obr, Iowa Dept. of Natural Resources 
Date: Tue, 08 Jul 2003 14:58:47 -0500

From: Urban.Trevor@epamail.epa.gov

Subject: Ames Laboratory

To: kayser@ameslab.gov

X-Mailer: Lotus Notes Release 5.0.9a January 7, 2002

X-MIMETrack: Serialize by Router on EPAHUB11/USEPAUS(Release 5.0.9a |January

7,2002 ) at $07 / 08 / 2003$ 03:58:48 PM

I hope this takes care of the issue. Contact me at 913-551-7133 if you

have any questions. Thanks for your patients.

-.-- Forwarded by Trevor Urban/ENSV/R7/USEPAUS on 07/08/03 02:56 PM

Colleen Thomas

To: Trevor

Urban/ENSV/R7/USEPAIUS@EPA

07/01/03 04:07 PM cC:

Subject: Ames Laboratory

Trevor,

RCRAlnfo is finally working. I made the changes to the Ames Laboratory sites and they are both marked as Non-Generators. Unfortunately, there's no good/easy way to mark a facility as Inactive in RCRAlnfo, but at least they're in there as non-generators. If you need anything else done to these sites, let me know.

Colleen Thomas

Tri-Cor Industries, Inc.

@EPA Region VII

913/551-7182 


\section{Department of Energy \\ Ames Site Office \\ 9800 South Cass Avenue \\ Argonne, Illinois 60439}

DEC 212005

Dr. Raymond L. Orbach, Director

Office of Science

SC-1 FORS

\section{SUBJECT: ENVIRONMENTAL MANAGEMENT SYSTEM IMPLEMENTATION}

Pursuant to DOE O 450.1, "Environmental Protection Program", paragraph 5d.(1), I am submitting this memorandum to report that Ames Laboratory fully conforms to the Environmental Management System (EMS) requirements of DOE 0450.1.

This declaration is based on a second party assessment of the EMS. The assessment was conducted using the self-declaration procedure described in attachment 2 of DOE G $450.1 \mathrm{~A}$ and was conducted as a component of implementing DOE O 226, "Implementation of Department of Energy Oversight Policy."

The requirements of DOE O 450.1 , as reflected in the contract requirements document, are incorporated into the site contract as part of the Work Smart Standards.

The site contractor has updated its approved Integrated Safety Management System (ISMS) Description to include the EMS requirements of DOE O 450.1. I have confirmed this as part of the self-declaration procedure described above.

I have ensured, through the annual ISM review process pursuant to DEAR 970.5223$1(e)$, that the contractor's Environment, Safety and Health (ES\&H) performance objectives, performance measures, and commitments are incorporated into an ISMS/EMS and include appropriate environmental elements based on the environmental risks, impacts of activities at the site, and established Departmental pollution prevention/energy efficiency goals.

Documentation supporting these determinations is available for review.

If you should have any questions please contact Mike Saar, of the Ames Site Office, at (630) 252-2245.

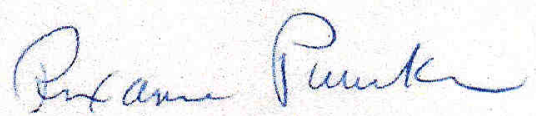

Roxanne Purucker, Manager Ames Site Office

cc: Don Erbschloe, SC-3, FORS

Leah Dever, SC-31, GTN

Sat Goel, SC-31.1, GTN 